\title{
エッジャ圧延による厚板の歩留り向上
}

\author{
西崎 允*·小久保一郎 ${ }^{* 2} \cdot$ 早川 初男* \\ 川谷 洋司*·福田 正彦*·吉間 豊*
}

\section{Improvement of the Yield by Edging Method in Plate Rolling}

\author{
Makoto Nishizaki, Ichiro KokUBo, Hatsuo HayakaWA, \\ Hiroshi KaWATANI, Masahiko FUKUdA, and Yutaka Yoshima
}

\begin{abstract}
Synopsis:
It is important to improve the plane view patterns of plates, in order to increase the yield of steel plates. For this purpose, edging method is examined by a laboratory test using lead plates, so that optimum edging condition is established, and the results are applied to actual plate rolling.

The results are as follows:

(1) By the edging method, plane view patterns are improved with the yield increase of about $2 \%$.

(2) The edging method is more effective when both top-bottom edging and side edging are carried out.
\end{abstract}

(3) The edging method is also effective to diminish the side overlap of heavy plates.

\section{1. 緒骨}

厚板庄延に括いて鋼板の長さ方向先後端部括よび幅方 向端部が圧延時に不均一な塑性変形挙動を示すために形 状は矩形とはならず, 形状不良部が発生する.また，板 厚が大きい場合には板厚断面において 折れ込みが生じ る.これら形状不良部は厚板製品の歩留りを左右する重 要な因子であり，これらの改善のための压延技術の開発 は厚板慜造に和ける重要な課題である.

厚板压延恃通常 1) 成形仕延，2）幅出し圧延，3）仕 上げ圧延の3過程に分かれ, 压延材は板幅比（板幅／板 厚）の比較的小さい成形压延および幅出し压延過程にお いて影著な满広がりを生じる。この幅広がり現象は圧延 材の長さ方向中央部と先後端部とでは挙動が異なり, 特 に先後端部で局部的な幅広がりが発生する。このように 幅広がりの不均一により压延材の平面形状は矩形からは ずれ, 先後端部では舌状あるいはフィッシェテール状を 呈し，幅方向ではつつみ状あるいはたいこ状となる.

さらに，板厚か $50 \mathrm{~mm}$ をこえるような厚物銅板の場 合は，压延時における板厚表層部と内部の伸び差に起因 する折れ込みが先後端部就よび幅方向端部に発生する.
これら形状不良部はいわゆるクロップロスとなり厚板 製品の歩留りを低下させる大きな要因となつてきた。 そ こで, 近年, 寸法の正確な連鋳スラブの使用比率の増加 とあいまつて平面形状の制御に関する技術開発が盛んに なり，厚板の歩留り向上に大きな成果を上げっつある.

厚板の平面形状献する制御方法としては，压延中の 鋼板の平面形状変化を予涀し，その変化に応じてスラブ 形状を圧延途中ハヘスで変化させる圧延技術が開発され， 矩形度の向上飞効果を上げている1).

一方，圧延時の局部的な幅広がりによつて生じる形状 不良部を直接制御し，銅板の矩形化をはかるとともに折 れ込みを減少させる方法としてェッジ＼cjkstart压延が有効であ ることが従来から知られている. 最近では压延材の土ッ シシング前の幅変動量に応じてェッシシング量を制御するこ とにより矩形度を改善しょらとする試みるなされてい る2). しかし，生延に上る銅板の平面形状変化は長さ方 向怙よび幅方向の端部における局部的な 3 次元変形に起 因しており，これはスラブ寸法，製品寸法などの寸法条 件和よび圧延条件によつて異なる。従つて，最適エッジ ング条件はスラブ構成，設備仕様の異なる個々の王延ラ インの特性に応じて確立する必要がある.

昭和 56 年 3 月16日受付 (Received Mar. 16, 1981)

* (株) 神声彆銈所加古川製鉄所 (Kakogawa Works, Kobe Steel, Ltd., 1 Kanazawa-cho Kakogawa 675-01)

*2. (株)神戸製銅所加古川製鉄所 工博. (Kakogawa Works, Kobe Steel, Ltd.) 
著者らは実壪の1/10 スケールで鉛板を用いて压延モ デル実験を行い，ェッジャ压延およびそれに綍く水平压 延による平面形状の变化過程について調查を行つた. 本 モデル実験から得られた結果を実機に竞用し，エッジャ 压延法により大きな歩留り効果を得たので報告する。ま た，折れ込みに対するエッジャ殴延の効果についても実 機で確認した.

\section{2. モデル圧延実殒}

\section{$2 \cdot 1$ 实駼方法}

供試材として厚さ $12 \mathrm{~mm}$, 幅 $100 \mathrm{~mm}$, 長さ $200 \mathrm{~mm}$. の硬質鉛板を使用した. 圧延にはワークロール径 100 $\mathrm{mm}$ の 4 段圧延機とロール径 $100 \mathrm{~mm}$ の㹂型圧延機を 用いた. エッシシンクのタイミングは Fig. 1 に示すよう に実操業工程の代表例を考虑して決定した. エッジンク は成形圧延後スラブを $90^{\circ}$ 回転し, 長さ方向を圧下する すの（以下 T-B エッシシンクと称する），と幅出し圧延後 スラブを再度 $90^{\circ}$ 回転し, 幅方向を圧下するすの（以下 サイドェッシシンクと称する) に分けて実施した. 幅出し 比は 1.5, 2.1, 2.6 の3種類とし, 水平圧下率は 1 バス 当たり $10 \%$ 一定で最終 $0.96 \mathrm{~mm}$ まで圧延した.な お，エッジング量は座屈を考虑して最大 $4 \mathrm{~mm}$ とした。 クロップ量については Fig. 2.に示す方法により決定

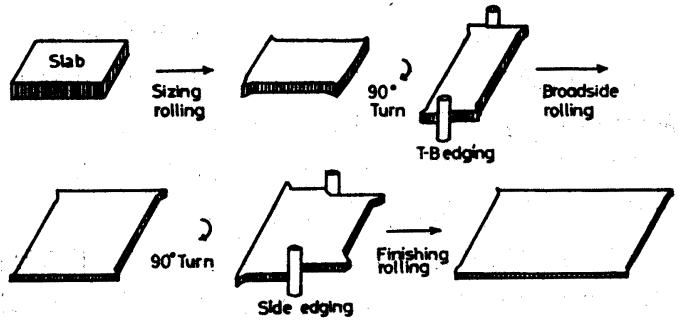

Fig. 1. Schematic illustration of typical edging process.

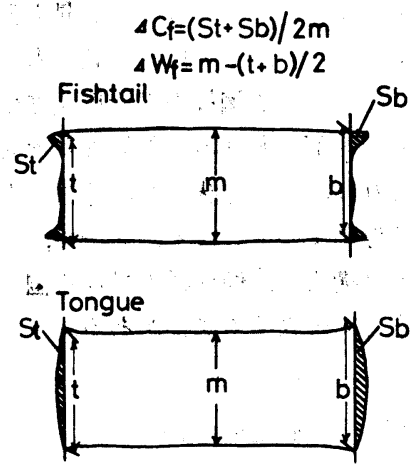

Fig. 2. Definition of endcrop length.
した. 先後端クロッブ長さ $\left(\Delta C_{f}\right)$ についてはクロップ 部の面積から矩形換算クロッブ長さを求め, 幅異形量 $\left(\Delta W_{\mathrm{f}}\right)$ Kついては長さ方向中央部の愊から先後端ク口 ップ部の蝠を引いた值を用いたななお，先後端クロップ 長さは形状がフィッシュテール状の場合を正とし，甜 の場合を負とした.

\section{$2 \cdot 2$ 实臨佶果と模討}

\subsubsection{T-B エッジングの効果}

压延終了後のクロップ量におよぼす T-B エッジンク の影㬖を調查するため, サイドェッジンク過程を省略し て T-B エッジンクと水平圧延のみを行つた．その結果 を Fig. 3 に示す. T-B エッシシング量 $\left(\Delta E_{\mathrm{c}}\right)$ を大きく すれば幅方向の形状はたいこ状からつづみ状に变化す る. すなわち幅出し比に応して T-Bエッシンク量を䔔 切に選ぶことにより愢異形量 $\left(\Delta W_{f}\right)$ を需とすることが 可能である.これは T-B エッシンクを行らことにより スラブの先後端部で幅方向に材料移動がょこり，幅出し 圧延時に生じる材料の欠損部分を補充することができる ためである. 従つて, 幅出し比が小さい場合に T-B エ ッシシング量を大きくしすぎると幅異形量は增加する。

先後端クロップ長さ $\left(\left|\Delta C_{\mathrm{f}}\right|\right)$ は，幅出し比が小さい (1.5) 場合には T-B エッシシンク量の增加とともに影著 に增大する。一方，幅出し比が大い $(2.1,2.6)$ と T-B エッジング量が小さい間はほとんど変化しないが,

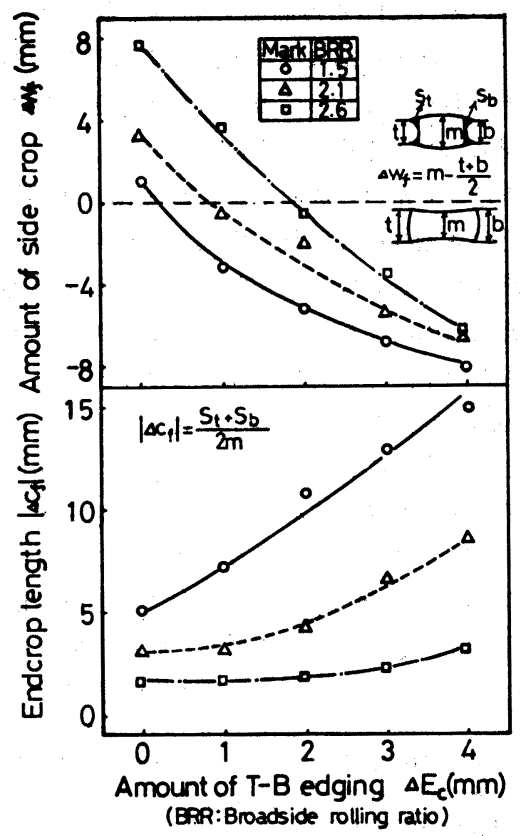

Fig. 3. Effect of T-B edgimg on plane view pattern. 


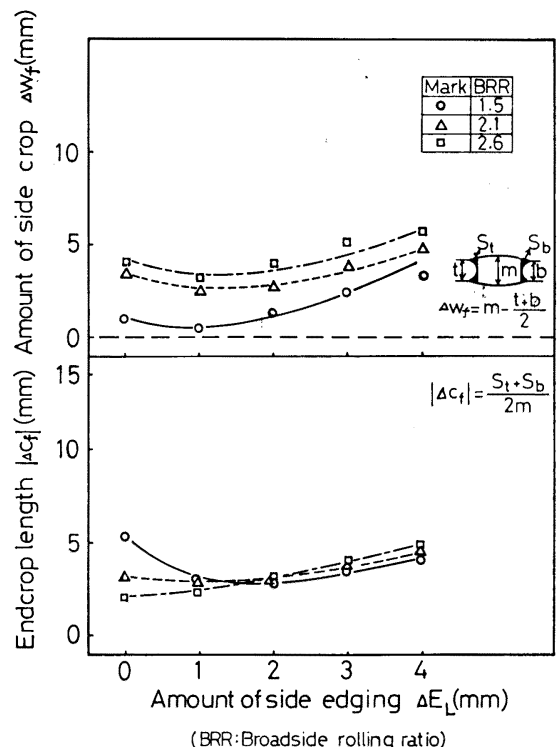

Fig. 4. Effcct of side edging on plane view pattern.

$\mathrm{T}-\mathrm{B}$ エッジング量が大きくなると増大する，また，幅出 し比が大きいほどその勾配は小さい。この機構について は基本的には井端ら ${ }^{3)}$ の考え方で説明できる.

従つて, T-B エッジングは幅出し比が大きい場 合に は幅異形量の減少に対して有効であるが，幅出し比の小 さい時には幅異形量, 先後端クロップ長さともに増大さ せる.

\section{$2 \cdot 2 \cdot 2$ サイドェッジングの効果}

次にサイドェッジングのみの効果を調査するために, サイドェッジングと水平圧延のみを行つた. その結果を Fig. 4 に示す. 本実験範囲内では, 幅方向の形状はすべ てたいこ状を示し, サイドェッジング量を大きくすれば 幅異形量はわずかながら増大する，また，幅出し比が大 きい注ど幅異形量は大きい。

先後端クロップ長さは幅出し比 1.5 の場合, サイドェ ッジング量を大きくすると極小点を持つが，幅出し比

2.1 以上では単調に増加する傾向を示す. また, サイド エッジング量が $2 \mathrm{~mm}$ 以上では幅出し比が大きくなる ほど先後端クロップ長さは大さな值を示す。

従つて, サイドェッジングは幅出し比の小さい場合に 有効であり， T-B エッジングとは逆の効果を示す.

$2 \cdot 2 \cdot 3$ T-B エッジングとサイドェッジングの組み合 わせの効果

以上の結果から幅異形量および先後端クロップ長さに およぼす T-Bエッジング, サイドェッジングそれぞれ 単独の効果が明らかとなつた. これらの結果から T-B

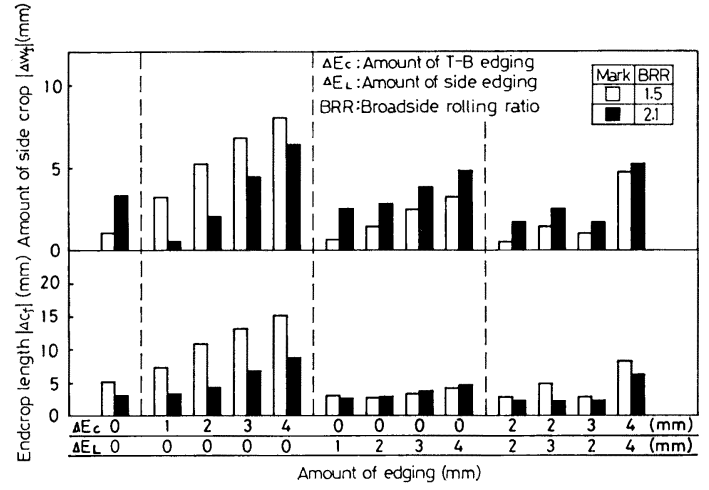

Fig. 5. Improvement of plane view pattern after finishing rolling by combined edging.

エッジングあるいはサイドェッジング単独の場合よりも 組み合わせを行つた方が全体のクロップ量は小さくなる ことが推測される.

そこで，T-B エッジングとサイドェッジングを組み 合わせた場合に幅異形量および先後端クロップ長さがど のように変化するかを幅出し比別に調查した. その結果 の 1 例を Fig. 5 に示す. 本図から幅異形量および先後 端クロップ長さそれぞれについて T-B エッジングある いはサイドェッジングのみの場合よりも低い值とする組 み合わせが存在し，その組み合わせは幅出し比によつて 異なつていることがわかる. しかし, 同一幅出し比にお いて幅異形量と先後端クロップ長さを最小とする組み合 わせは異なつており，全体のクロップ量をできるだけ小 さくする適切な組み合わせを見出す必要があることを示 している.

\section{$2 \cdot 3$ 最適エッジング条件の検討}

圧延終了後の平面形状は圧延各段階で形成された形状 の合成された結果であるから, 平面形状の制御方法を確 立するためには各圧延段階における平面形状の変化量を 寸法条件および圧延条件の異なるものについて把握し， その量に応じた制御を行ら必要がある.

そこで, 圧延工程を Fig. 6 に示すように 3 つの領域 に区分し, 各領域最終での形状と次領域での形状変化に ついて調査を行つた.

まず，領域 Iすなわち幅出し圧延後の形状におよぼす T-B エッジングの効果を Fig. 7 および Fig. 8 に示 す. 幅出し圧延終了後の幅異形量 $\left(\Delta W_{1}\right)$ は Fig. 3 に 示した仕上げ圧延後の幅異形量の変化と同様の傾向とな るが，両者を比較すれば仕上げ圧延過程において幅異形 量はつづみ状に向からことがわかる.

先後端クロップ形状は T-Bエッジング量が大きくな 


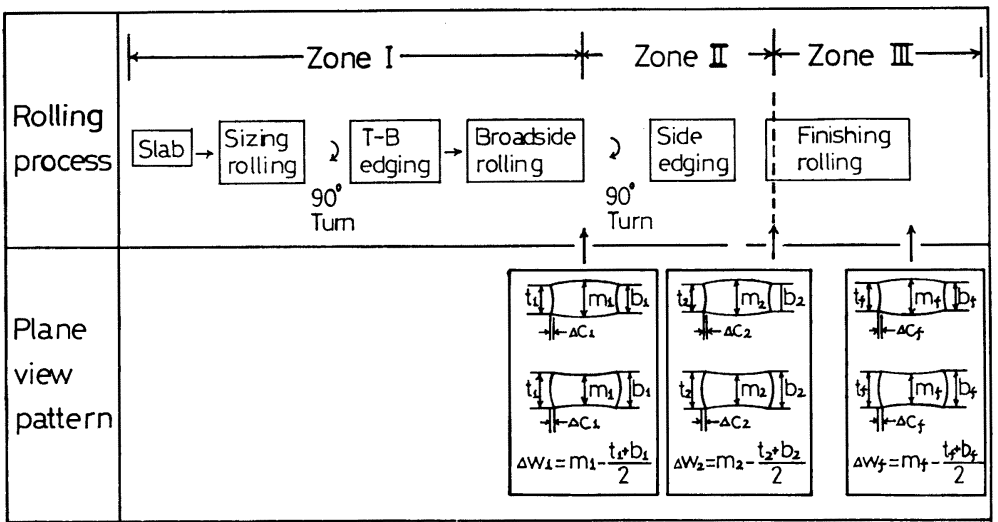

Fig. 6. Shematic illustration of rolling process and plane view pattern.

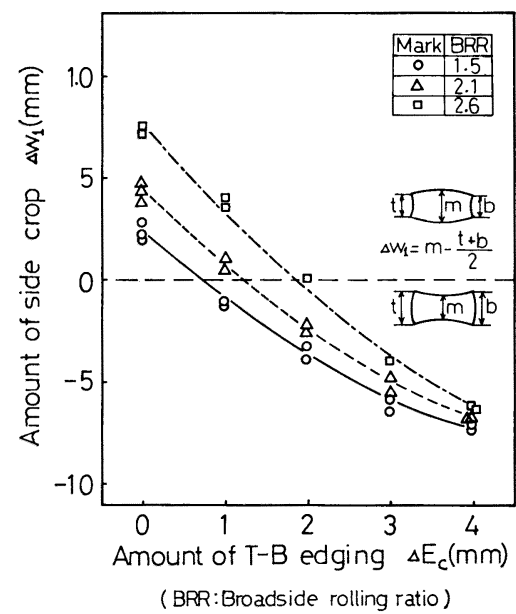

Fig. 7. Effect of $\mathrm{T}-\mathrm{B}$ edging on side crop afrer broadside rolling for different broadside rolling ratios.

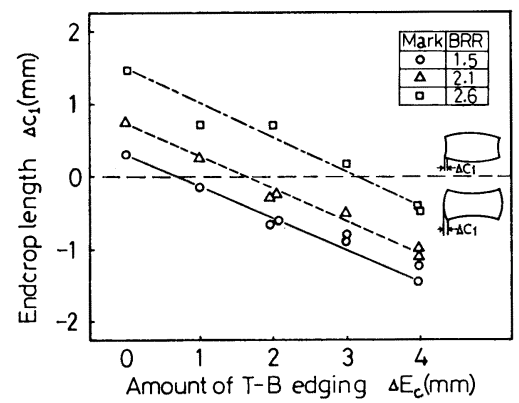

(BRR:Broadside rolling ratio)

Fig. 8. Effect of $\mathrm{T}-\mathrm{B}$ edging on endcrop length after broadside rolling for different broadside rolling ratios.

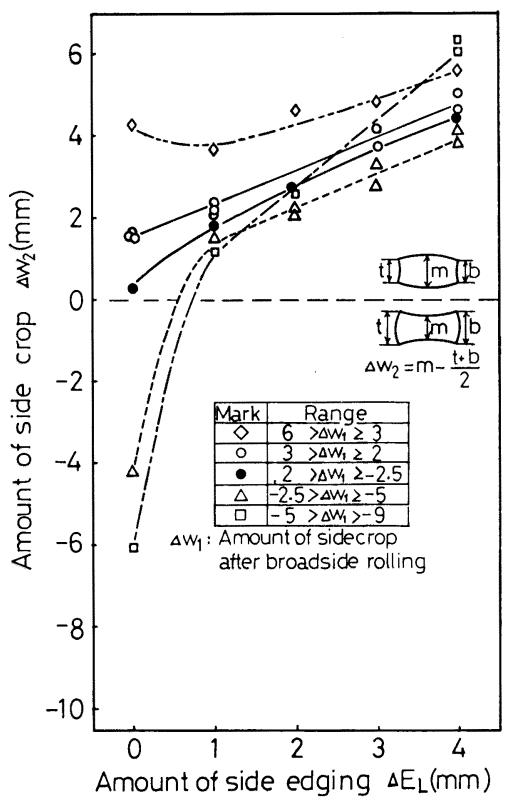

Fig. 9. Effect of side edging on side crop after first finishing rolling pass for different $\Delta W_{1}$.

るに従いフィッシュテール状から舌状に変化する. フィ ッシュテール形状は幅出し圧延時の局部的な幅広がりに 起因するものであるから, 幅出し比が大きいほど幅出し 圧延終了後の先後端クロップ形状は大きなフィッシュテ ール状となり, 舌状とするための T-B エッジング量も 大きくなることを示している.

次に, 領域IIすなわち幅出し圧延完了後の形状がサイ ドェッジングおよびそれに続く仕上げ圧延を 1 パス行つ た後にどのように変化するかを調查した結果を Fig. 9 および Fig. 10 に示す.

サイドェッジング量の増加とともに幅異形量は大きな 


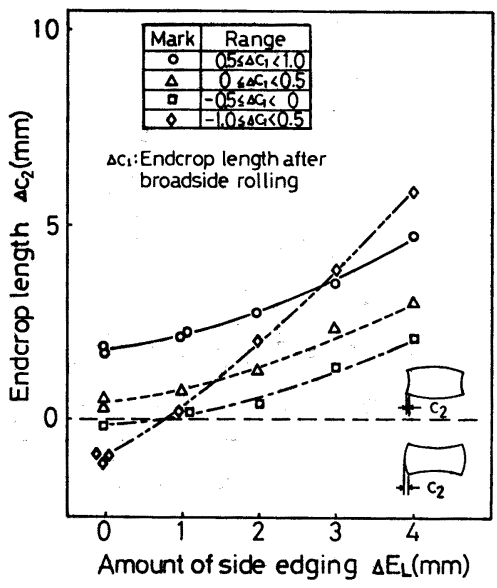

Fig. 10. Effect of side edging on crop length after first finishing rolling pass for different $\Delta C_{1}$.

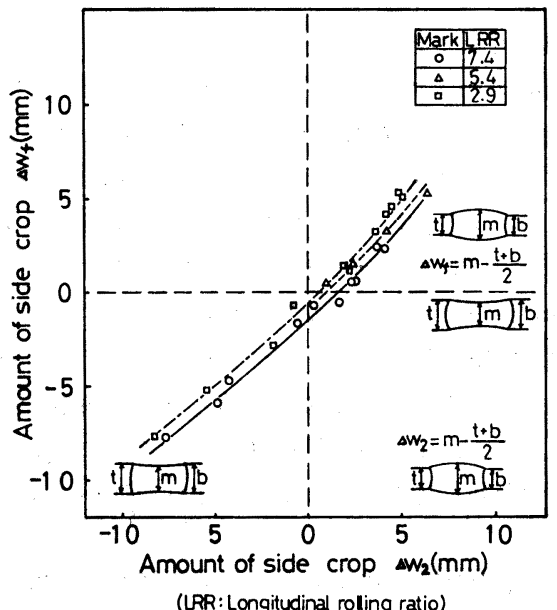

Fig. 11. Relation between side crop after first finighing rolling pass and side crop after finishing rolling for different longitudinal rolling ratios.

たいこ状となり，先後端クロップ長さは大きなフィッシ ニテール状となる.

一方，幅出し压延後の幅巽形量が小さなつつみ状の場 合 (Fig. 9 の $\Delta$ 印) に比べて大きなつつ及状の場合 (Fig. 9 の口訶) にはサイドエッジング量の増加ととも により大きなたいこ状となる. 先後端クロップ形状につ いても同棣の傾向があり，大きな舌状のるの (Fig. 10 の口印）をサイドェッジングすると極端なフィッシュテ 一ル状となる.これらの現象す井端ら゙)の考方方で説明 できる.

従つて，幅出し比が小さい場合に $\mathrm{T}-\mathrm{B}$ エッシシンク量 护よびサイドェッジング量を大きくしすぎると幅方向で

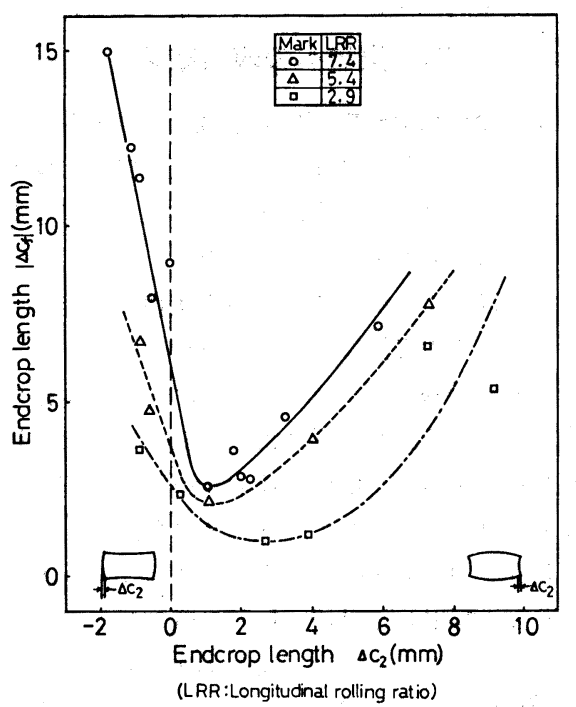

Fig. 12. Relation between endcrop after first finishing rolling pass and end crop length after finishing for different longitudinal rolling ratios.

はたいこ状の幅異形量, 先後端部ではフィッシュテール 長さが極端に大きくなることを示している.

次に，領域正すなわち仕上げ压延過程での形状変化を Fig. 11 および Fig. 12 と示す. 仕上げ圧延1ハス後の 幅異形量 $\left(\Delta W_{\mathbf{2}}\right) \cdot$ がたいこ状の場合は仕上げ圧延により その値は小さくなるが，つつみ状の場合には大きな值と なる. また，仕上げ圧延延伸比が大きいほど压延終了後 の幅異形量はつつうみ状となる值向がある．これは仕上げ 圧延過程に和いて定常部に比べ先後端部の幅広がり量が 大きく，仕上げ压延延伸比が増加するほどその差が大き くなることを示している.

压延終了後の先後端クロップ長さは Fig. 12 に示す ように極小值をるち，仕上げ压延延伸比が大きいはどそ の値は大きくなる．また，この極小值を与兄る仕上げ圧 延 1 パス後の先後端クロップ長さ $\left(\Delta G_{2}\right)$ は仕上げ圧延 延伸比が大きいほど小さな值となる.これは仕上げ压延 過程に怙いて幅方向端部に比べ中央部の方が長さ方向へ の伸び量が大きく, 両者の伸び量の差は仕上げ王延延伸 比が增加するほど大きくなることを示している。

従つて, Fig. 12, Fig. 13 の関係から王延終了後の 幅異形量および先後端クロップ長さを最小とする仕上げ 圧延 1 パス後の幅異形量および先後端クロップ長さが決 定される.

Fig. 7〜Fig. 13 に示した結果から圧延終了後のク口 ップ量を最小とする T-B エッジング量およびサイドェ ッジング量の組み合わせを幅出し比, 仕上げ圧延延伸比 
に応じて定量的に決定することが可能である.

\section{3. 实殿への道用結果}

モデル実験の結果から圧延終了後の平面形状を矩形に 近づけるためには仕上げ圧延 1 パス後の愊異形量书よび 先後端クロップ長さを仕上げ压延延伸比に応して制御す る必要があることが明らかとなつた。

そこで，以上のモデル実験結果と実機での経験にもと づきェッジャ使用方法についての標準を作成した. 基本 的な考方方は Fig. 13 に示すとおりである.本標準を実 機に適用し，压延実験を行つた．供試スラブは連鋳スラ ブを主として使用し, 偪出し比および仕上げ圧延延伸比 はそれぞれ 1.1〜2.6 および3〜9 の範囲で行つた.

幅異形量は Fig. 14 に示すようにェッジャ圧延を行 わない場合, 幅出し比 1.3〜1.5 を境としてつつる状と たいこ状に分かれる. 幅出し比が 2.5 以上の場合に幅異 形量は $100 \mathrm{~mm}$ 近くになるが,最適エッジング条件から 決定されたェッジャ圧延を行らことにより $\pm 30 \mathrm{~mm}$ 以

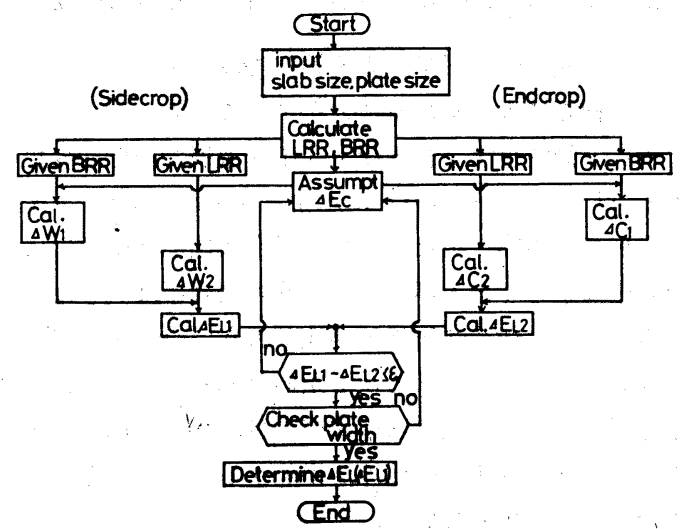

$\Delta \mathrm{E}_{\mathrm{L}_{1}}$ : Amount of side edging for minimizing sidecrop. $\Delta \mathrm{E}_{\mathrm{L} 2}$ : Amount of side edging for minimizing endorop.

Fig. 13. Flow chart for determination of edging condition.

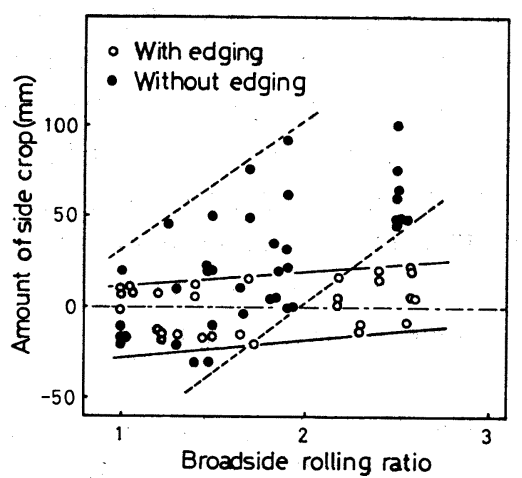

Fig. 14. Improvement of side crop by edging.

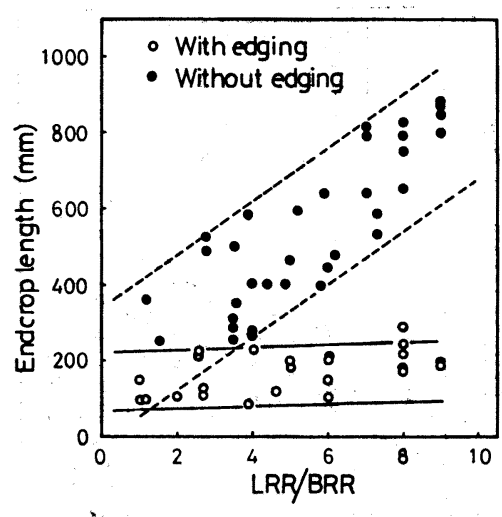

(BRR: Broadside rolling ratio) (LRR: Longitudinal rolling ratio)

Fig. 15. Improvement of endcrop length by edging.

内に制御可能である.

先後端クロップ長さは Fig. 15 に示すようにエッジ ヤ圧延を行わない場合，（仕上げ圧延延伸比/幅出し比の 增加とともに直線的に增加する傾向がある. しかし, 最 適エッシシグ条件により T-B エッジング量およびサイ ドェッシンング量を制御することで先後端クロップ長さを $200 \mathrm{~mm}$ 以下にすることが可能である.

なお，実際の操業では Fig. 13 に示したェッジンク 条件は主として寸法の正確な連鋳スラブに䔔用し,シャ 一だれあるいは手入時の溶削部分が大きいスラブに対し てはその形状に応じてェッジング条件を使い分けてい る.

一方，製品厚が $50 \mathrm{~mm}$ をこ学るような厚物銅板を圧 延した場合, 先後端部および幅方向端部で折れ込みが生 じる.この理由は板厚の大きい銅板の王延では板厚方向 の昰み分布が不均一となり，板厚中心部に比べて表層部 の伸びが大きくなるためである.エッジャ圧延は板厚内 部と表層部との伸び差によつて生じたダブルバレルの凸 部を直接圧延するため, 折れ込みが発生するまでに板厚 断面を平坦にすることができる.

厚さ $300 \mathrm{~mm}$ 以上のスラブを供試材としてェッジャ 圧延を通用した場合の折れ込み量の変化を Fig. 16 お よび Fig. 17 に示す. 先後端部拈よび幅方向端部に発 生する折れ込みはエッシシングにより著しく改善されてい る.

以上の上5にエッジャ压延法は銅板の平面形状を矩形 化するらえで非常に有效であり，厚物銅板の折れ込みに 対しても効果がある.ささらに，直接幅制御を行えるため 板幅精度の向上にる有効である.これらの結果をスラ 


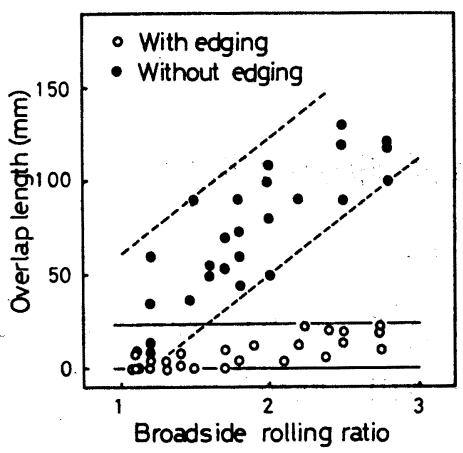

Fig. 16. Improvetment of overlap length at side edge by edging.

ブ設計に反映させることにより歩留りは約 $2.0 \%$ 向上す る.

\section{4. 蛣}

E

鉛板を用いたモデル王延実験を行いエッジャ圧延によ る平面形状の改善効果について調査を行つた. 本実験の 結果から最適エッジング条件を検討し，これを実機に適 用することにより効果を確認した.

今回の実験で得られた桔果は次のよ5た要的される.

1) エッジャ圧延により平面形状の矩形化および折れ 込み量の低減が可能となり，これによる歩留りの向上は 約 $2.0 \%$ である.

2) 仕上げ圧延 1 パス後の最適平面形状を得るための エッシシング条件を検討し，エッジャ使用条件の最適化を 行つた。この結果を実機に適用することにより幅異形量 を $\pm 30 \mathrm{~mm}$, 先後端クャップ带さを $200 \mathrm{~mm}$ 以下にす ることが可能である.

3）全体のクロップ量を減少させるためには T-B工 ッジンク，サイドェッジングそれぞれ単独よりる雨者を 組み合わせることが必要である。

4） T-Bエッジングは幅出し比が大きい鋼板の幅 異

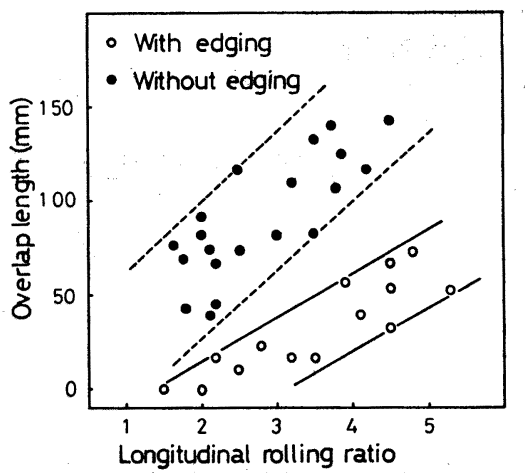

Fig. 17. Improvement of overlap length at endcrop by edging.

形量を堿少させるが，幅出し比の小さい鋼板に対しては 幅異形量, 先後端クロップ長さとも増加させる。

5) サイドェッシンングは幅出し比の小さい銓板の矩形 度を向上させるのに有効である。

今回, エッジャ設定条件を最適化することによりエッ ジャ圧延法の効果を確珰することができた。.今後, 圧延 幅とロールクラウンの影整を考虑して, エッジャ制御の 精度を高めることによりさらに歩留りを向上させること が可能である。 また，エッジャ使用にとるなう生産性の 低下に関しては粗ミル，仕上げミル2スタンド体制のも とでミルペーシングの最適化をはかるとともにパススケ ジュールの改善を行うことにより対処できるすのと考兄 ている.

\section{文献}

1) K. Tsubota, H. Kikugawa, $K$. Baba, and S. Isoyama: Proc. of International Conferen ce on steel Rolling, Sept.-Oct, 1980, Vol. 1. p. 193

2) 笹治峻, 久津輪浩一, 堀部晃, 野原由勝, 山田稳久，渡辺和夫：鉄之鋼，66(1980), A 165

3) 平野 坦, 小久保一郎, 井端治広: 第 28 回塑性 加工連合講演会講演論交集, $(1977,11)$, p. 101 